\title{
Bergerova konstruktivistická sociologie vědění jako kritika vědomí
}

\author{
Berger's Constructivist Sociology of Knowledge as a Critique \\ of Consciousness
}

Karel Hlaváček

\begin{abstract}
The article deals with the tension between „,value-freeness“" or ,objectivity“ and the critical intention in the sociology of Peter L. Berger. I put forward the thesis that Berger's approach to this problem is inconsistent: Berger often claims his sociology to be value-free, but close investigation discovers implied value-laden contents, consisting in an appeal to human freedom in existentialist sense of the word and critique of what is inconsistent with this appeal. In the article, I analyse this inconsistency and identify the points through which these values leak into Berger's sociology. I suggest that the value contents are essential to Berger's sociology, which is why his work should be read as an outline of a critique of consciousness.
\end{abstract}

KEY WORDS objectivity, value-freeness, critique, social constructivism, Peter Berger

\section{Úvod}

Padesátileté výročí vydání Bergerovy a Luckmannovy The Social Construction of Reality (Sociálni konstrukce reality) je bezesporu př́íhodným momentem, v němž lze komentovat inspirace, které Berger a Luckmann do sociologie prrinesli, či znovupromýšlet a analyzovat jejich dílo. Této prŕležitosti se chce chopit i tento text. ${ }^{1}$ Věnuje se přitom jednomu ze základních napětí v Bergerově sociologii vědění: napětí mezi objektivizující a hodnotově nezatíženou vědou, kterou Berger hlasitě a jednoznačně podporoval, a kritikou stavu lidského vědomí, jež je neméně základním prvkem jeho sociologie. V Bergerovi se střetává Max Weber s Karlem Marxem a Alfred Schütz s Jean Paulem Sartrem. ${ }^{2}$ Jak se tento střet projevuje? Jak dokázal Berger skloubit hodnotovou nezatíženost s kritickou rovinou? To je základní otázka, kterou si klade tento text.

$\mathrm{V}$ textu se věnuji pouze Bergerovi, nikoli Luckmannovi. Nerozebírám přitom pouze The Social Construction of Reality, ale Bergerovo dílo jako celek. Tento ,celek“ je ovšem nutno

Sociální studia / Social Studies 3/2016. S. 21-36. ISSN 1214-813X.

1 Tento text vznikl na ISS FSV UK v rámci projektu Specifického vysokoškolského výzkumu SVV 2016 č. 260339.

2 Cílem tohoto textu není historizující rozbor jeho kořenů v dílech Sartra, Marxe, Schütze či Webera. Tyto kořeny jsou proto reflektovány pouze v nutné miřre; větší prostor je věnován právě napětí mezi snahou nehodnotit a snahou „osvobozovat“. Toto napětí je dostatečným tématem samo o sobě: vždyt' je to právě neshoda nad možností a vhodností emancipačního záměru a nehodnotícího př́ístupu, který sociologii rozdělil a rozděluje na kritickou teorii a popisné proudy. 
chápat s určitou výhradou - jedná se zejména o tu část Bergerovy tvorby, která bezprostředně souvisí s jeho konstruktivistickou sociologií vědění. Např. jeho spisy týkající se hospodářského rozvoje do mnou analyzovaného korpusu nespadají; stejně tak se systematicky nevěnuji rozboru jeho teologických textů. ${ }^{3}$

Prvotním motivem tohoto textu je obava, že Bergerovo dílo je v sociologickém kontextu často čteno jako ona hodnotově nezatížená sociologie, což vede k podceňování či přehlížení její potenciálně kritické roviny. ${ }^{4}$ Kritická rovina se ovšem - jak tvrdí tento článek - prolíná Bergerovými texty a je od nich neoddělitelná a nakonec se projevuje jako (pouze skicovitě navržený) etický základ Bergerovy sociologie, který je explicitními prohlášeními o hodnotové neutralitě pouze zamlžován. ${ }^{5}$

Text ale nezůstává u konstatování toho, že kritická rovina je u Bergera př́tomna, nýbrž blíže rozebírá její vztah $\mathrm{k}$ Bergerově hodnotové neutralitě a objektivitě. Přichází přitom s tezí, že Bergerovu sociologii je možno pochopit jako teorii, která má náběh $\mathrm{k}$ tomu, stát se kritickou teorií v širokém slova smyslu. Tedy sociologií, která empirii doplňuje o filosofické a hodnotové zázemí, na jehož základě potom probíhá kritika stavu společnosti (v Bergerově př́padě kritika typu vědomí). ${ }^{6}$ Toto „,doplněni““ se nicméně u Bergera nachází pouze v zárodečné formě - a ucelenou kritickou teorii tak netvoří.7 Snažím se nicméně ukázat, že „objektivní“ empirii

3 Bergerovo dílo zřejmě není možné přesvědčivě rozdělit např. na pozdní a rané nebo vědecké a popularizační. Kritické motivy totiž nacházíme u raného i pozdního Bergera, u Bergera pracujícího vědecky i popularizačně, u Bergera vědeckých statí i u Bergera reflektujícího povahu oboru obecně (viz dále v textu).

4 Toto tvrzení lze podložit např. průběhem letošní konference České sociologické společnosti u př́ležitosti 50. výročí vydání Sociálni konstrukce reality, na němž se kritická interpretace Bergera nesetkala s pochopením (byla zde kritizována jako nepochopení nehodnotícího charakteru Bergerova sociálního konstruktivismu). Ovšem i v českém kontextu existují texty, které Bergerovo dílo uchopují včetně jeho kritické dimenze nebo na ni alespoň upozorňují. Tak např. Radim Marada hovoří o Bergerově a Luckmannově „existenciálním humanismu“, jehož kritický rozměr popisuje mimo jiné jako „univerzalizaci schématu zbožního a peněžního fetišismu“ (Marada 1999: 210), která míŕi „proti sebeklamům, ke kterým se rádi utíkáme my všichni“ (Marada 2004). Stanislav Hubík mluví o tom, že koncepce Bergera a Luckmanna dospěla k variantě Marxovy teorie odcizení (Hubík 1999: 178). V mezinárodním kontextu nacházíme zmínku o zvěcnění u Bergera u Very (2016: 14), podrobnější rozbor přinesl Zerubavel (2016) nebo Baehr (2013) (viz dále v textu), hodnocení vlivu Bergera na kritický náboj sociologie vědění nabídl Sica (2016: 38).

5 Problém možné redukcionistické četby Bergera jde dokonce ještě dále: Berger totiž byl a je věřícím křest’anem, konkrétně liberálním protestantem, a v rámci svého díla „,nekoketuje“ pouze s kritickými záměry svých textů, ale i s tím, jak intelektuálně sladit „metodologický ateismus“ sociálních věd s osobní vírou v křest’anského Boha. Pro hlubší analýzu těchto motivů u Bergera viz Woodhead (2001) nebo Fuller (1987).

$6 \quad$ Kritická teorie, jak ji v tomto textu chápu, nemusí být levicově zaměřená, a dokonce ani zaměřená na politickou změnu. To je ostatně typ kritiky, který je sociologii vědění vlastní - vzpomeňme na Mannheimovu sociologii vědění.

$7 \quad$ S tímto typem četby koreluje Baehrova (2013) interpretace, jež ovšem na rozdíl od mé kritizuje Bergerův kritický záměr a chce ho opustit; rezonuje taktéž s četbou Zerubavelovou (2016: 74), který považuje koncept „Zvěcnění“ za nejdůležitější koncept celé The Social Construction of 
v Bergerově případě nelze od jejího hodnotového zázemí jednoduše „odtrhnout“, protože hodnoty se nachází spíše ,před“ či ,za“ Bergerovou empirickou sociologií než „po“ ní.

Text je rozdělen na tři části. V první části rozebírám argumenty a podklady, které hovoří pro četbu Bergera jako objektivního empirického sociologa, v druhé se pak přesouvám k identifikaci motivů, které hovoří pro to, že jeho sociologie má tendenci pokládat základ pro vytvoření kritické teorie. Poslední část se zabývá rozborem napětí mezi těmito dvěma póly Bergerova díla a identifikací jeho prř́čin.

\section{Berger jako objektivní sociolog}

Berger sám sebe často prohlašuje za hodnotově neutrálního či objektivního sociologa. Jak ř́ká Jeremy H. Gill (1988: 256): „Berger se zásadním způsobem opírá o pojem objektivity“ a přijímá „,základní dichotomii mezi ř́śší hodnot a ř́ŕší faktů“. Tento postoj nalezneme u Bergera od jeho raných spisů až po jeho autobiografii, kterou v tomto textu - přestože Berger nadále žije - interpretuji jako symbolické uzavření jeho díla. ${ }^{8}$

Toto „oddělovací“ stanovisko považuje Berger za mimořádně důležité. V jeho díle ho nacházíme zdůrazňované znovu a znovu. V The Social Construction of Reality tak s Luckmannem věnuje úvodní pasáž oddělení empirické sociologie a filosofie. Píše, že „filosof je nucen (...) rozlišovat mezi platnými a neplatnými tvrzeními o světě. Sociolog se takto chovat nemůže“ (Berger a Luckmann 1999: 10). Sociolog nerozhoduje o tom, co je svoboda, nebo existuje-li Bůh. Spíše bude zkoumat, jaké „realitě“ v tomto směru lidé věří. Jinými slovy, sociolog se ,nedopouští“ ontologických výroků, ale zkoumá, co lidé považují za ontologicky skutečné.

Právě ve jménu svého typu „oddělovacího stanoviska“ pak Berger ještě na počátku nového tisíciletí kritizuje na jedné straně „,metodologický fetišismus“ jakožto převládnutí metod (zejména těch kvantitativních) nad obsahem, na straně druhé ,přeměnu sociologie z vědy v nástroj ideologické obhajoby“ (Berger 2002 in Berger 2003: 177). ${ }^{9}$ Právě kritika

Reality, a to v kontextu, který je přímo navázán na Gramsciho koncept kulturní hegemonie (netematizuje ale napětí mezi vědeckou objektivitou a zvěcněním v Bergerově díle).

8 Již ve svém Invitation to Sociology (Pozvání do sociologie) Berger prohlašuje, že sociolog, ,aby se nám intelektuální strava beznadějně neznečistila“ a byla „,košer“, nesmí „nalít mléko subjektivního pocitu na maso vědecké interpretace“ (Berger 2003: 129). Berger sice současně tvrdí, že „nic není vzdálenějšího záměrům autora, než vystoupit s obhajobou pozitivistického kréda“, které chápe jako redukci reality na její vědecky uchopitelné aspekty a označuje ji za ,intelektuální barbarství“ (Berger 2003: 129), ale současně se jasně staví za oddělení vědecky uchopitelné reality od přemýšlení nad jejími dalšími aspekty, jako jsou např. svoboda, existence Boží a jiné filosofické nebo teologické otázky.

9 Berger při své kritice podoby sociologie na přelomu tisíciletí nešetří silnými slovy. Metodologický fetišismus podle něho vedl k tomu, že se ze sociologie vytrácejí velké otázky a sociologové řeší čím dál banálnější a nicotnější otázky pomocí čím dál důmyslnějších metod: „Potřebují k tomu, aby se dostali do nejbližšího vykřičeného domu, milionový grant.“ Ideologizace sociologie ale podle Bergera měla ,ještě pustošivější účinky“. Ideologové vědu deformovali „,v nástroj agitace a propagandy (komunisté tomu rríkali agitprop) vždy ve prospěch levé strany ideologického spektra. 
ideologizace sociologie je jedním z nejsilnějších argumentů, které mohou být použity ve prospěch četby Bergera jako „objektivního“ sociologa.

Když Berger předestírá vlastní podobu sociologie, vymezuje se právě proti dvěma výše zmíněným pozicím. Na jednu stranu se nechce propadnout do „uctívání metody“, na druhé straně ani do marxizující ,ideologie“. Jakou střední cestu tedy nabízí?

Podle Bergera je sociologie „způsob vidění“ (way of seeing), který odkrývá to, co není na první pohled zřetelné, ale co „funguje podle pravidel, která je ještě třeba objevit, ,pod kolektivními strukturami, jak byly ,oficiálně definovány normativními disciplínami, jako jsou teologie, filosofie a právo“ (Berger a Kellner 1982: 11). Za typicky „sociologickéc tak Berger považuje např. známé Mertonovy pojmy manifestní a latentní funkce: zatímco filosofie, teologie a právo se zaměřovaly na funkce manifestní, sociologie odhaluje funkce latentní. Berger v tomto smyslu hovoří o „specifickém úhlu pohledu (...), který je esencí sociologie: pod viditelnou stavbou lidského světa je skrytá, neviditelná struktura zájmů a sil, které čekají na to, až je sociolog odhalí. ,Manifestní není vše; je zde ještě ,latentní, jež je třeba studovat“. Základní zvěstí sociologie proto je: „Svět není takový, jaký se zdá být“ (Berger a Kellner 1982: 12). ${ }^{10}$

Sociologie tak má pro Bergera subverzivní účinky. Studiem „latentního“ totiž odkrývá to, co nebylo vidět a co bylo vědomě či nevědomě zakrýváno. Nemusí být přitom jasným záměrem sociologa věci subverzivně odkrývat. Berger tvrdí: „Sociologie přináší ,subverzie, jakmile aplikuje na sociální realitu svi̊j specifický způsob vidění (...). Je tomu tak bez ohledu na to, jestli ten který sociolog má subverzivní záměr. Vskutku, velké postavy klasického období sociologie - Émile Durkheim, Max Weber, Vilfredo Pareto - mohou být všichni popsáni jako tak či onak konzervativní, a kromě marxistů byla většina sociologů nanejvýše umírněnými reformisty spíše než revolucionáři. Jakkoli konzervativní ale byly jejich záměry, myšlení těchto sociologů mělo hluboce narušující kvalitu, která zneklidňovala a pobuřovala ty, kteří měli vsazeno na to, že se věci mají jevit podle oficiálních definic“ (Berger a Kellner 1982: 12-13).

Právě z toho, že sociologie je subverzivní „sama od sebe“, vyvozuje Berger kritiku „ideologické" sociologie. Vždyt’ jestliže je subverzivní sama od sebe, k čemu je třeba „,ideologie“? Podle Bergera ,jsou sociologové vždy na štíru se svojí vlastní disciplínou, pokud chtějí hrát roli advokátů - nebo, přesněji, pokud tak chtějí činit jakožto sociologové“. Sociologie nemůže podporovat ani „konzervativní“, ani „revoluční“ a ani jiné pozitivní zájmy: „génius sociologie je negativní“ (Berger a Kellner 1982: 13).

Základní vědecká zásada objektivnosti se v praxi ignoruje a v teorii se popírá její oprávněnost“ (Berger 2002 in Berger 2003: 180). Ideologizace sociologie je podle Bergera „marxizující“, opakuje mantru „třída, rasa, gender“ a je spojena s odporem proti kapitalismu, globalizaci a s obavami o životní prostředí. Berger se přitom obává, že „spolu s metodologickým fetišismem je ideologická propaganda zásadním faktorem v úpadku sociologie, a to nejen v Americe“ (Berger 2002 in Berger 2003: 180-181).

10 Tohoto rysu si povšiml např. Peter Baehr, který Bergerovu sociologii nazývá „,sociologií demaskování“ (Baehr 2013: 379). 
Berger si uvědomuje, že negace existujícího již obsahuje odhalování skrytého, více či méně otevřeně předpokládá možnost redefinice oficiálních definic: „Nejen že svět není tím, čím se zdá být, ale mohl by být jiný, než je“ (Berger a Kellner 1982: 13-14). Právě proto, že svět je možno měnit, pak sociologové jako Durkheim mohli chtít využít svoji sociologii i ve službách racionálního spravování společnosti. ${ }^{11}$

Berger tedy rozpoznává, že nehodnotící či objektivní sociologie koneckonců stojí ve službách určitého typu hodnot (racionální spravování společnosti), nadále ji však obhajuje: domnívá se, že sociolog nemůže chtít zastávat nějakou „ideologii“. Sociolog prý chce jen poznávat „latentní“ funkce různých společenských jevů; jeho zájem zůstává nehodnotící a kognitivní. To, zda jeho vědění má, či nemá nějaké subverzivní či konzervativní dopady, se děje jaksi „samo od sebe“, spočívá to v „esenci sociologie“, v jejím specifickém úhlu pohledu.

Jak a v jakém smyslu je nehodnotící a objektivní sociologie pro Bergera možná? Pro Bergera je samožrejmé, že v aktu interpretace (který je ve weberovsko-schützovské sociologii jejím základním kamenem) se mohou odrážet osobní charakteristiky sociologa: jeho věk, pohlaví, vyznání, výchova atp. Tyto faktory ale podle něj může sociolog kontrolovat. Může si říct: „ted’ dělám sociologii“, resp. řečeno odborně, může přijmout „,vědeckou strukturu relevance“. V té se sociolog zrííká svých osobních hodnotových představ, bere jako základ „všeobecně prrístupný soubor teorie a dat“ (Berger a Kellner 1982: 53) a akt interpretace provádí na jeho základě. Řečeno fenomenologickým jazykem, sociolog své hodnoty „uzávorkuje“; pokud to neučiní, „vědecký podnik zkolabuje, a to, co sociolog věří, že vnímá, není ničím více než jeho nadějemi a strachy, přáními, resentimenty a jinými psychickými potřebami; co potom vnímat nebude, je cokoli, co by mohlo být nazýváno sociální realitou“ (Berger a Kellner 1982: 56).

Pro Bergera tedy sociolog musí podniknout „volní akt“, v němž se zřekne svých hodnot, aby viděl nezávisle na nich. Tento nehodnotící pohled je pak základem toho, co lze podle Bergera nazývat „objektivitou“ v sociologii. „Objektivita“ či nehodnotící věda je nicméně rovněž opozicí vůči ,ideologii“; tj. podle Bergera, jestliže je sociolog „objektivní“, ideologii „uzávorkuje“, zbavuje se jí. Berger má představu, že výše popsaný postoj sociologa, v němž je přijata „vědecká struktura relevance“, se současně odráží v „čistším“ poznání. Objektivita má tedy subjektivní a objektivní stránku: po subjektivní stránce sociolog provede „uzávorkování" svých emocí a sklonů a ideologií, což poté přináší plody po objektivní stránce: poznání je „objektivní", tj. nenarušené ideologií.

11 Právě v této chvíli Berger - snad nejzřetelněji v rámci svých „weberovských“ spádů - naráží na jejich hranice, totiž na to, že subverze sama je určitou hodnotou, a to hodnotou vycházející z ideálů osvícenství. Říká: „Tento ,spravovací ‘ motiv v sociologii má samozřejmě svůj původ, a to ve vazbě na ideály osvícenství, v aspiraci na založení racionálnějšího a pravděpodobně humánnějšího sociálního řádu. V tomto směru byla sociologie, stejně jako ostatní sociální vědy a obecně sociální myšlení od 17. století, součástí mnohem širšího pohybu západního myšlení“ (Berger a Kellner 1982: 14). 


\section{Bergerova konstruktivistická sociologie vědění jako kritika vědomí}

Bergerova sociologie - jak vyplývá z výše nastíněného - chce být subverzivní. Otázka, kterou musíme položit, zní, jestli je možné, aby byla subverzivní „sama od sebe“, což je názor, $\mathrm{k}$ němuž tenduje Berger, nebo je tomu spíše tak, že jeho sociologie koření v určitých hodnotách (v proudu osvícenského západního myšlení), což je skutečná příčina oné subverzivnosti. Abych tuto otázku zodpověděl, pátrám po hodnotách, z nichž Bergerova sociologie vychází.

Toto pátrání můžeme začít u základního díla sociálního konstruktivismu, The Social Construction of Reality. Berger a Luckmann totiž v této knize užívají marxovský pojem „Zvěcnění, který obsahuje hodnotící náboj. Píší:

(J)akmile je ustanoven objektivní sociální svět, je otevřena cesta pro zvěcnění. Objektivita sociálního světa znamená, že ho člověk vnímá jako něco, co existuje mimo něj. (...) Zvěcnění může být popsáno jako extrémní krok v procesu objektivace, $\mathrm{v}$ jehož průběhu objektivovaný svět přestává být vnímán jako lidský výtvor a je trvale pojímán jako nezměnitelná skutečnost, s níž lidé nemají nic společného. (...) Zvěcnění znamená, že člověk je schopen zapomenout na své vlastní autorství světa. (...) Zvěcnělý svět je tedy světem dehumanizovaným. Člověk ho prožívá jako podivnou skutečnost, spíše jako opus alienum, dílo cizí, nad nímž nemá žádnou moc. (Berger a Luckmann 1999: 90)

Věty jako „Zvěcnělý svět je světem dehumanizovaným“ nelze „odkouzlit“ do weberovského nehodnotícího typu sociologie: v žádném případě se nejedná o „Zvěcněni“ bez hodnotového náboje. Není tomu ovšem ani pouze tak, jak se domnívá Gill (1988: 256), že totiž Bergerova tendence $\mathrm{k}$ objektivitě je v první řadě negována jeho relativistickým konstruktivismem; kromě toho je totiž negována Bergerovým př́klonem k existencialisticky orientovaným koncepcím vyjádřeným marxistickými pojmy - a tyto pojmy relativistické nejsou.

V tomto směru nás nenechává na pochybách zejména zásadní článek „Reification and the Sociological Critique of Consciousness“, který Berger napsal ve spolupráci s Pullbergem (Berger a Pullberg 1965) a v němž systematičtěji rozvádí pojetí konceptů „zvěcnění, „odcizení“ a „falešné vědomí“. Tyto tři pojmy jsou vlastně označením pro tentýž fenomén, vždy z odlišného úhlu pohledu. Odcizení Berger definuje jako „proces, v němž je jednota mezi tvůrcem a tvořeným narušena. Produkt se nyní jeví produkujícímu jako cizí fakticita a síla stojící sama o sobě proti němu, a není nadále rozpoznatelná jako produkt" (Berger a Pullberg 1965: 200). Odcizení je tedy v podstatě stav, v němž se ocitá člověk, který si neuvědomil pravdu sociální konstrukce reality, ale věrí nějakému typu zakouzlené reality, např. tomu, že svět včetně jeho sociálních charakteristik byl stvořen Bohem.

Koncept zvěcnění je obdobný pojetí zmíněnému v The Social Construction of Reality. ${ }^{12}$ Berger ř́ká: „Zvěcněním míníme moment procesu odcizení, v němž se charakteristika

12 Zdá se pravděpodobné, že pojem zvěcnění prosadil právě Berger, protože zmiňovaný článek o sociologické kritice vědomí (Berger a Pullberg 1965) byl publikován rok před vydáním The Social Construction of Reality (1966); v The Social Construction of Reality se nicméně neobjevuje např. pojem odcizení, což Berger s Luckmannem zdůvodňují rozkolísaností jeho významu (Berger a Luckmann 1999: 193); zde lze naopak usuzovat na Luckmannův vliv; jinak totiž Berger tento pojem používá. 
věcnosti (thing-hood) stává standardem objektivní reality. To znamená, že nic, co by nemělo charakter věci, nemůže být uznáno za reálné (...). Zvěcnění je objektifikace ${ }^{13} \mathrm{v}$ odcizeném modu“ (Berger a Pullberg 1965: 200). Zatímco „odcizení“ popisuje stav, v němž se nachází člověk, „Zvěcnění“ je stav, který odcizený člověk připisuje realitě, tj. jedná se o vlastnost reality, nikoli o vlastnost člověka.

$\mathrm{K}$ popisu stavu člověka, který je odcizen, pak Berger používá pojmu falešné vědomí. Berger říká: „Vědomí světa i sebe může být označeno jako falešné vědomí - falešné v tom smyslu, že reálný proces, v němž vzniklo já a jeho svět, je zapomenut. Pokud falešné vědomí dosáhne teoretické formulace, funguje jako mystifikace (anebo, pokud tento pojem preferujeme, jako ideologie - ačkoli bychom se v současném kontextu tohoto pojmu rádi vyvarovali)“ (Berger a Pullberg 1965: 205). Tento pojem se tedy vztahuje užším způsobem na „vědomí“ člověka než „odcizení“.

Pojmy „Zvěcnění“, „odcizení“ a „falešné vědomí“, zdá se, tvoří etický či hodnotový podklad Bergerovy sociologie. Jeho sociologie chce být subverzí toho, co chápe jako nežádoucí stav vědomí - již název článku, v němž pojmy specifikuje, přece ř́ká, že se jedná o „sociologickou kritiku vědomí“. Jedná se o nástin několika pojmů, které by dále mohly být rozpracovány v kritickou teorii, která by byla zaměřena na „osvícení “ lidského vědomí tak, aby si z ontologického hlediska uvědomilo „skutečnost“ sociální konstrukce reality a nepropadalo „mystifikaci“ božského či jiného ne-lidského původu světa. ${ }^{14}$

Pojmy jako „falešné vědomí“ nebo „odcizení“ nespadají do Gillem nastaveného protikladu: nejsou objektivistické, ani relativistické v empirickém smyslu. Jsou hodnotící a současně předpokládají, že jsme schopni objevit nějaký „správný stav“ vědom. Je ovšem pravdou, že Gillem rozebírané napětí způsobené Bergerovým sklonem ke konstruktivistickému relativismu se zde nakonec musí projevit: onen „správný“ stav vědomí by znamenal vědomost o relativitě, jejíž hranice nejsou jasně vymezeny. Pokud by se ovšem relativita šiříla bez ohledu na jakékoli hranice, musela by nakonec zasáhnout „objektivitu“ i ony pojmy jako

13 Berger odlišuje „objektivaci“ a „objektifikaci“: zatímco „objektivaci“ pojímá jako způsob, kterým člověk vstupuje do intersubjektivního prostoru, „objektifikace“ je zpředmětnění objektivace, je to př́stup k objektivacím jako k předmětům (Berger a Pullberg 1965: 199-200).

14 Kořeny Bergerových „výzkumných zájmư“ $v$ úvahách inspirovaných marxistickými pojmy nejsou součástí nějakého jednorázového „úletu“ pod vlivem spoluautora výše citovaného článku Pullberga. V tomto článku sice zřejmě nalézáme nejzřetelnější formulaci hodnotových základů Bergerovy sociologie vědění, definici zvěcnění nicméně nacházíme i v klíčovém díle The Social Construction of Reality (viz výše), stejně jako v díle The Social Reality of Religion (Berger 1969, vyšlo také pod názvem The Sacred Canopy). V tomto díle Berger používá marxovské pojmy stále v tomtéž smyslu, v jakém již byly popsány: „Odcizení je radikalizovaná objektivace. Sociální svět je zvěcněn. (...) Aktér nečiní, nýbrž je skrze něho činěno. Jednání se jeví jako určení, jako osud“ (Berger 1973: 93). A ke zmíněným hodnotovým pojmům se Berger hlásí i na konci své kariéry, ve své autobiografii: „Náboženství účinně posiluje ,realitu` institucí, protože je jakoby kosmologicky ukotvuje: Nejsou to lidé, kteř́ se rozhodli takto jednat. Nařídili jim to bohové. (...) V této souvislosti jsem zjistil, že rané marxovské kategorie ,odcizení a ,zvěcnění jsou dosti užitečné (aniž bych proto musel souhlasit s pozdějším korpusem Marxových spisů)“"(Berger 2012: 96). 
třeba „falešné vědomí“. Bergerova sociologie tak v tomto směru připomíná partikulární kritiku ideologie, která sama nepočítá s tím, že by i ona mohla být ideologií. ${ }^{15}$

Bergerova sociologie tedy předpokládá masivní hodnotové zázemí, které Berger vyjadřuje pomocí přizpo̊sobených marxovských pojmů. Jejich význam u Bergera nicméně není ani tak marxistický jako spíše existencialistický. ${ }^{16}$ Ve své autobiografii popisuje svoji sociologii (konkrétně první vydanou knihu A Precarious Vision) následujícím způsobem: „Společnost je strukturou fikcí. Tyto fikce jsou vtěleny v rolích, které společnost připisuje jednotlivcům. Jak se jednotlivci v důsledku socializace identifikují se svými rolemi, začnou tyto fikce tvořit morální alibi. Jinak řečeno, fikce umožňují to, co Jean-Paul Sartre nazýval falešnou vírou (mauvaise foi): jednotlivci jednají, ale předstírají, že nejednaji“‘ (Berger 2012: 72).

Berger tedy explicitně nenavazuje ani tak na Marxe, jako zejména na Sartra a jeho představu o „falešné víře“. Marxistické pojmy jsou u Bergera použity tak, aby tvořily apel na lidskou svobodu v sartrovském smyslu. Od díla A Precarious Vision se přitom Berger nedistancuje: píše sice, že se jedná o ,mladistvou perspektivu“, ale současně dodává, že jeho kniha „nastiňuje sociologickou perspektivu, za jejíž správnost bych se dodnes zaručil, i když s určitými změnami“ (Berger 2012: 72). V posledku jde u Bergera o motiv apelu na lidskou svobodu, o to, aby si lidé uvědomili, že o svém jednání rozhodují oni, ne nějaká předem naordinovaná sociálně daná ,pravda““. ${ }^{17}$ Jak říká Baehr (2013: 381), Berger chce být „humanistickým“ sociologem a jeho humanismus chce spočívat v „přispění sociologie k vytvoření humánní společnosti, které je založeno na odhalování mýtů legitimizujících krutost a útlak“.

15 Zde je možné se Bergerovi po vzoru Gilla „vysmívat“ pro jeho „epistemologickou naivitu“ (Gill 1988: 256). Gill tak činí s ohledem na Bergerovo přijetí dichotomie faktu a hodnoty na jedné straně a relativismu na straně druhé. $\mathrm{K}$ tomu bychom nyní mohli přidat i naivitu ohledně nedostatečně reflektovaného zapojení pojmů, které nereflektují dichotomii mezi fakty a hodnotami ani nejsou relativistické. Neměli bychom se ale unáhlit. Právě Bergerův sklon k epistemologické naivitě v sociologických spisech je totiž zpětně relativizován v Bergerových teologických spisech. Např. Bergerova kniha The Rumour of Angels nás nenechává na pochybách, že Bergerovo dílo by zasloužilo být analyzováno nejen odděleně ve smyslu oddělené sociologie a teologie, ale $\mathrm{v}$ jednotné perspektivě. Berger na jednu stranu kritizuje (nejen) náboženství za jeho tendenci ke „Zvěcnění“, na druhou stranu v teologických spisech kritizuje moderní myšlení - a tato kritika by, vzato do důsledku, mohla zasáhnout jak dichotomii faktu a hodnot, tak pojmy jako falešné vědomí, které tuto dichotomii překračují, stále jsou ale bytostně moderní. Berger říká: „V moderním světě existuje typ vědomí, který má problémy s nadpřirozenem. (...) Uživatelé elektřiny a rádia jsou intelektuálně zařazeni nad apoštola Pavla. To je dost legrační. Člověk se nemůže ubránit hroznému podezření, že totiž nakonec má navrch apoštol Pavel““ (Berger 1971: 58).

16 Jádro kritiky nespočívá v kritice institucí, nýbrž v kritice vědomí. Podle Baehra se jedná o dědictví „osvícenských vizí, znovu uchopených moderním existencialismem“ (Baehr 2013: 381).

17 V tomto Berger zmiňuje i Heideggera a jeho pojem „das Man“ (do češtiny překládané jako „ono se“), které člověku umožňuje vyhýbat se zodpovědnosti: „Není to ani ten, ani onen člověk, který něco bude nebo nebude dělat, ani vy, ani já - jsou to určitým způsobem všichni lidé, ale tak obecně, že to stejně tak dobře nemusí být nikdo. (...) Existovat autenticky znamená žít s plným vědomím jedinečnosti. (...) Naproti tomu neautentická existence je ztráta člověka v anonymitě onoho das Man“ (Berger 2003: 149). 
Nebo, jak konstatuje Zerubavel (2016: 70), Berger kritizuje „esencialismus“, který pouhou „konvenci interpretuje jako absolutní, objektivní, a tedy současně nevyhnutelnou“.

Celým Bergerovým dílem se tak táhne existencialistická stopa vyjádřená v marxistických pojmech: je totiž právě důsledkem ,zvěcnění“, „odcizení“ a „falešného vědomí“, že se sociální role stávají neprůhlednými a člověk jich nevědomky využívá k tomu, aby se zbavil odpovědnosti za své činy. Kritiku zvěcnění u Bergera je v první řadě třeba chápat takto: jedná se o kritiku stavu vědomí s cílem toto vědomí osvobodit tak, aby si uvědomilo svoji odpovědnost za vlastní jednání. Bergerova sociologie z tohoto hlediska není, jak se zdá, nějakou hodnotově neutrální sociologií - předpokládá zásadní hodnotové obsahy. Nejedná se ale ani o pouhou implicitně obsaženou subverzi nebo nenápadně podsouvanou relativizaci. Jde v posledku o letmý nástin několika pojmů, které by zřejmě mohly být rozpracovány do podoby kritické teorie. Na pochybách v tomto směru nás opět nenechává Bergerův článek, který již ve svém názvu nese pojem „kritika vědomi““ (critique of consciousness) - jedná se o nástin kritiky stavu lidského vědomí.

Jak na tuto existencialistickou filosofickou stopu navazuje Bergerovo sociologické dílo? Celá The Social Construction of Reality může být (a měla by být) čtena jako mimorádně důsledné cvičení v relativizaci sociálních konstruktů tak, aby relativizovalo ,falešné vědomí". ${ }^{18}$ Její zvěstí (alespoň z Bergerova úhlu pohledu) je právě ona „subverzivnost“", kterou jsem analyzoval výše, zpráva, že instituce nejsou absolutní a mohly by vypadat i jinak. Z toho pak plyne, že není možné je ,odcizeně“ považovat za nezávislé na člověku. Cvičením v relativizaci společenských institucí ale není jen The Social Construction of Reality - je vlastností konstruktivistické sociologie vědění jako celku.

Relativizace se jako zásadní motiv prolíná Bergerovou sociologií vědění jako takovou, a to ještě dříve, než byl teoreticky zformulován sociální konstruktivismus - vzpomeňme jen na Bergerův vlastní komentář k jeho první knize, v níž chce ukázat společnost jako „strukturu fikcí" v sartrovském slova smyslu. Totožný je záměr Bergerova Invitation to Sociology, které Berger koneckonců sám označuje za verzi onoho ličení společnosti jako struktury fikcí (Berger 2012: 76). Stejný motiv je základem knihy The Social Construction of Religion (Berger 1969), kterou se Berger cítil povinován doplnit teologickým dílkem A Rumour of Angels (Berger 1971), v němž prezentoval svoji teologickou pozici, protože po četbě prvně jmenované knihy vznikal díky prolínající relativizační tendenci dojem, že se jedná o „cvičení v ateismu“ (Berger 1971: 9). Není snad nutno rozvádět motiv „subverzivnosti“ jako základu Bergerova díla dále: vždyt’ on sám ho označuje za základní definiční vlastnost sociologie (viz výše).

Sociologie vědění je u Bergera relativizací ve službě osvobození vědomí od „odcizení“; je snahou proměnit „zvěcnělý“ (a tedy dehumanizovaný) svět ve svět lidský. Jak říká Berger sám: „Sociologie je př́buzná komedii, protože odhaluje sociální fikce. Ze stejného důvodu je potenciálně osvobozující. Ukazuje v pravém světle ,špatnou víru', jež umožňuje jednotlivcům skrývat se za svými rolemi, a nutí tak tyto jednotlivce, aby se nějak vyrovnali s realitou své svobody“ (Berger 2012: 73).

18 Berger ostatně ř́íká: ,Je důležité vidět sociologii jako jednu z manifestací prohlubujícího se pocitu relativity v moderní historii Západu“ (Berger a Kellner 1982: 61). 
Na tomto místě samozřejmě vyvstává řada otázek: jak daleko je možno relativizaci sociálního světa provádět? Máme relativizovat pouze naše role? Všechny role, nebo pouze některé? Máme snad relativizovat všechny lidské výtvory včetně jazyka? Je to vůbec možné? A co je „Za“ rolemi, jestliže je relativizujeme? Není člověk nakonec rolemi „ontologicky“? Na některé z těchto otázek upozorňuje už Drápalová (2004): „Dobrá tedy, ale kam až můžeme zajít ve své touze demaskovat sociální systémy? Kde jsou hranice našeho zájmu? Kdo posoudí, kam až můžeme zajít?“ Dalšími otázkami by mohly být: Jaká je u Bergera antropologická představa člověka a jeho svobody? Jak přesně vypadá etické jádro, na němž je snaha „osvobozovat“" postavena? A tak dále a tak podobně. ${ }^{19}$

Radikální a hlasitou kritiku marxizující „,ideologie“ v sociologii, kterou Berger provádí, je proto třeba vnímat zejména v kontextu Bergerova konzervativního politického směřování. Bergerova kritika marxistů může být těžko brána vážně, směřuje-li proti ,ideologizaci“ sociologie - vždyt' on sám sociologii ,ideologizuje“ specifickým typem emancipačního záměru, který spočívá v osvěcování lidského vědomí ohledně charakteru společenských institucí. Bergera kritická teorie ve své většinové podobě dráždí, protože je levicová, protože její hodnotové směřování jde Bergerovi natolik „proti srsti“, že nedokáže „uzávorkovat“ svoji živelnou nechut' vưči ní. Ta zřejmě pramení ze setkání s jejími nesnášenlivými verzemi. ${ }^{20}$ Bergerova kritika kritické teorie ovšem nemění nic na tom, že jeho vlastní dílo může být čteno jako její specifická a konzervativní forma, která se zaměřila na potírání „zvěcnělého“ vědomí.

\section{Problematické soužití kritiky a objektivity u Bergera}

Bergerovo vymezení sociologie, jak bylo nastíněno výše, otevírá nevyjasněnou otázku, jak je možné považovat sociologa za „objektivního“, jestliže je oddán duchu osvícenství, v jehož rámci vytváří takový subverzivní typ vědění, který více či méně explicitně prohlašuje, že realita by mohla být i jiná. Jak může používat pojmy typu „zvěcnění“ a „,falešné vědomi““ a odkazovat na hodnotově nabité koncepty „svobody“ nebo „,autenticity“ existencialistů? Jestliže se sociolog nesmí dopouštět fillosofických (ontologických) výroků, které přenechává

19 Berger si uvědomuje důležitost některých z těchto otázek a řeší je - jeho knihy jako In Praise of Doubt nebo Between Relativism and Fundamentalism hledají odpovědi na hranice relativizace. V knize The Homeless Mind se pak Berger, jak upozorňuje Marada (1999), staví spíše jako konzervativec, který se obává situace, ve které už vědomí nemá, kde by našlo „domov“. Tato problematika - problematika hledání konkrétnějších obrysů Bergerovy „kritické teorie“ - by si nicméně zasloužila spíše samostatnou analýzu; v tomto textu není možno se jí podrobně věnovat. V každém případě se Berger rozvoji své „kritické teorie“ nevěnuje nijak systematicky - to zřejmě už z toho důvodu, že téměř vůbec otevřeně nehovoří o tom, že by se o kritickou teorii mělo jednat.

20 Berger má výraznou zkušenost s nesnášenlivou podobou marxizujících teorií. Viz kapitolu v Bergerově autobiografii týkající se jeho politického působení (Berger 2012: 153-176). Zde Berger specifikuje své špatné zkušenosti s „feministickou ideologií“ i své konzervativní směřování. Ř́ká např.: „Nedlouho poté mou přednášku na London School of Economics hlasitě narušil a ukončil vřískající dav. (Tyto lidi rozzuřilo mé konstatování, že sociologie je radikální ve své demaskující perspektivě, ale konzervativní ve svých praktických důsledcích)“ (Berger 2012: 155). 
filosofům, jak vůbec může tvrdit, že „realita je sociálně konstruována“? Jestliže, jak navrhuje Zerubavel (2016: 70), Berger kritizuje jako zvěcnění to, že intersubjektivita má tendenci být prohlášena za objektivitu, jak potom může prohlašovat vlastní sociologii za objektivní?

Domnívám se, že na tuto zdánlivě jednoduchou otázku Berger odpovědět nedokáže. Jeho základní odpovědí by mohlo být pouze to, že „pravda osvobozuje“: sociolog zjištuje, „jak věci jsou“, a kritika předsudků a osvobozovací potenciál se ve světle pravdy objevuje jaksi sám. Sociolog pouze poukáže na „skutečnost“ a „předsudek“ se sám zhroutí. Situace ale není zdaleka tak jednoduchá.

Bergerova sociologie vědění nemá subverzivní charakter „sama od sebe“ - výše popsané hodnotové základy jeho sociologie ukazují zcela jasně, že z hodnotového hlediska koření v existencialisticko-marxovském zázemí. Bergerova teze o tom, že objektivní věda může mít subverzivní účinky „sama od sebe“, je tak ohrožena v samém základu - zdá se spíše, že Bergerův způsob sociologického tázání vychází ze sartrovské představy svobody, a „objektivní“ empirickou sociologii následně formuje do poukazu tímto směrem. Formulace Bergerových výzkumných otázek vychází z určité představy svobody; kdyby Berger tuto představu neměl, otázky, které by pokládal, by nutně vypadaly jinak.

$\mathrm{Na}$ výše uvedeném by nemohlo nic změnit ani to, kdyby Berger marxovské a existencialistické pojmy explicitně nepoužíval. Tyto pojmy pouze explicitně popisují hodnotové zázemí, v němž Bergerova sociologie koření ${ }^{21}$ - a to bez ohledu na to, jestli to Berger reflektuje a popisuje, nebo ne; působí subverzivně, at' už si jejích fillosofických základů jsme vědomi, nebo ne. Jestliže si jich ovšem nejsme vědomi, neznamená to, že neexistují. Spíše jsme je zatím nebyli schopni objevit. ${ }^{22}$ Explicitní rozpracovávání obsahu pojmů, které mají sloužit jako základ kritiky, nicméně poukazují $\mathrm{k}$ tomu, že Bergerova sociologie nakonec není jen nějak „tišse“ subverzivní - jedná se o blíže nerozpracovaný nástin kritické teorie ve smyslu kritiky forem vědomí.

21 To naznačuje prioritnost hodnot vůči sociologické empirii. Tato prioritnost přitom ale není čistá i filosofické názory vznikají v kontaktu s empirickou realitou.

22 To lze doložit např. pomocí dopadů Bergerovy sociologie na čtenáře. Berger např. zmiňuje, že $\mathrm{v}$ důsledku jeho sociologie někteří lidé reálně ztratili náboženskou víru. Berger napsal dizertaci o náboženském proudu bahaismus; jednomu z vyznavačů ji pak dal přečíst. Následně se potkal $\mathrm{s}$ jeho ženou a došlo $\mathrm{k}$ tomuto rozhovoru: ,Jsem tak ráda, že vás potkávám. Musím vám poděkovat, že jste zachránil mé manželství! V následném rozhovoru vyšlo najevo, že náboženství bylo v tomto manželství hlavním zdrojem třenic: žena nemohla manželovu bahaistickou víru ani pochopit, ani se jí přizpůsobit. $\mathrm{V}$ důsledku četby mé dizertace však ztratil svou víru, a tak ukončil napětí mezi nimi“ (Berger 2012: 37-38). Takoví lidé bezesporu neuvažovali o marxovských a existencialistických základech jeho teorie - víru ztratili prostě proto, že jeho teorii pochopili a provedli aplikaci na svůj život, at' už v úvodu toho kterého textu Berger píše, že se jedná o nehodnotící sociologii (což je pravděpodobnější varianta), nebo že se jedná o výzvu ke svobodě (což Berger přiznává jen ve „slabších“ chvílích). Stejným směrem ukazuje i současné využití Bergerovy sociologie ve výuce. Relativizační potenciál Bergerovy sociologie vědění je využíván v aplikaci na vlastní život jako nástroj „osvícení“. Viz Chance (2004), který přináší reflexe studentů čtoucích Bergera ohledně jejich změny vnímání vlastního náboženského přesvědčení. 
Aby se Bergerova sociologie vědění stala subverzí, nemusí vůbec vědomě kořenit v existencialisticko-marxovských pojmech, tj. nemusí být pojmově specifikována jako hodnotově nabitá teorie; může být představena jako „nehodnotící“ sociologie. To měl Berger tendenci vidět jako vlastnost, která je v sociologii obsažena „sama od sebe“. Tak tomu ovšem není existencialistická představa o svobodě a o „falešné víře“ nebo „falešném vědomí“ z pozadí formuje Bergerovu „nehodnotící“ sociologii tak, že je systematickým poukazem na toto „falešné vědomí، 23

Je možné namítnout, že Berger a Luckmann v The Social Construction of Reality nenavrhují explicitně, že by mělo být něco změněno; že by legitimizace byla nějak ,špatná“ nebo že by „věděni'“ mělo být špatně. Podle tohoto pojetí by hodnocení bylo obsaženo teprve v explicitním návrhu, že je třeba změny. Nehledě k tomu, že tato výzva je nakonec explicitně obsažena v kritice ,zvěcnění“ u Bergera, není tento názor správný. V údajně nehodnotících výrocích je ve skutečnosti explicitně navrženo, že jestliže toto či tamto považujeme za nekonstruovanou „pravdu“, pak se mýlíme, protože ve skutečnosti se jedná o „sociální konstrukci“. Sociální konstrukce reality je u Bergera a Luckmanna ,pravdou“ s ontologickým nárokem, $\mathrm{v}$ jejímž jménu jsou kritizovány jiné ,pravdy“ s ontologickým nárokem, zejména ty, které dávají sociální realitu do spojitosti s ,přirozeností“, „Božím řádem“ atp.

Místem, kde je Berger nedůsledný, je oddělení sociologie od filosofie, empirie a ontologie. Kámen úrazu se skrývá ve výše citované pasáži z The Social Construction of Reality tvrdící, že sociolog se nesmí dopouštět ontologických výroků, protože ty jsou doménou filosofie. To Berger dobře rozpoznal, nicméně nedodržel. The Social Construction of Reality lze totiž shrnout do jednoho jediného ontologického výroku: realita je sociálně konstruována. Toto je představuje naprosto základní problém: chce-li totiž Berger zůstat sociologem v tom smyslu, který sám podporuje (a v němž se „,nedopouští“ ontologických výroků), může říct pouze, že neví, zda realita je sociálně konstruována, ale jakožto sociolog to předpokládá jako metodologický princip. Epistemologický status sociologie by nemohl být výše než předpoklad typu ,jako by to takto bylo“, nikdy ne ,takto to je“. ${ }^{24}$

„Hodnoty“, resp. komplexní filosofické zázemí, které bylo výše identifikováno jako existencialistické pojetí svobody specifikované pomocí přisvojení původně marxistických pojmů, do Bergerovy „nehodnotící“ sociologie pronikají skrze ontologický nárok teorie, která tvrdí, že realita je sociálně konstruována. Zde se sociologie dostává na stejnou úroveň jako ontologická tvrzení o povaze reality, kterým tak de facto konkuruje, resp. je kritizuje. Berger představuje konstruktivistickou sociální ontologii - a taková ontologie samozřjejě není kompatibilní

23 I naprosto „suché“ a objektivizující věty jako „funkcí legitimizace je učinit již institucionalizované ,prvoplánové‘ objektivace objektivně dostupnými a subjektivně věrohodnými“ (Berger a Luckmann 1999: 93) jsou ve skutečnosti nabity až výbušným relativizačním potenciálem, nebot’ stačí uvedenou abstraktní větu konkrétně aplikovat a obsahy, kterým jsme předtím mohli bezproblémově věřit, se nyní jeví jako jakési spiknutí, které nás má obalamutit.

24 Epistemologický status ,jako by“ by ale celou teorii odsoudil ke směšnosti. Těžko si představit, jak Berger ř́ká, že nesoudí pravdivost reality, a tedy ani pravdivost vlastní teorie, která vlastně nemusí být pravdivá (takového soudu se jako sociologové musíme vzdát), je pouze hrou na ,jako by“. Možná by pak bylo nutno změnit název knihy: Sociální konstrukce reality, anebo taky ne. 
s některými jinými ontologiemi. Tyto jsou pak ve jménu Bergerovy teorie kritizovány jako „zvěcnění“ a lidé, kteří je zastávají, jako „odcizení“ lidé s „falešným vědomím““. ${ }^{25}$

Stále by mohlo být namítnuto, že Berger přece v posledku jen porovnává „zvěcnělé“ vědění s „objektivními“ zjištěními vědy a kritizuje je za to, že tato „objektivní“ zjištění neberou v úvahu, tedy kritizuje v rámci vědy. Taková námitka vlastně pracuje s tím, že Berger nekritizuje „morálně“, ale „,epistemologicky“. Není však oprávněná.

I epistemologická kritika je kritikou morální - je přece nemorální ,ž̌ít ve lži“‘. Berger nás koneckonců nenechává na pochybách o tom, že důsledkem „falešného vědomí“ jsou morálně „špatné“ důsledky. Lidé se schovávají za své role; např. soudce může odsuzovat ve jménu Božím, a zakrývat tak svoji svobodu - včetně osobní zodpovědnosti za život obviněného, kterou ale podle Bergera nelze přehazovat na bohy. Bergerovým záměrem je „probrat“ lidi k jejich svobodě a odpovědnosti. To je morální rozměr Bergerovy kritiky.

V Bergerově případě je obtížné stanovit, nakolik si je filosofických předpokladů své teorie vědom a nakolik je sám před sebou zastřel tvrzeními o ,hodnotové neutralitě“ a „objektivitě“. Nejzřetelnější uvědomění tohoto problému nalezneme opět v článku „Reification and the Sociological Critique of Consciousness“, kde Berger zcela zřetelně uznává své filosofické (a tedy v rámci jeho porozumění rovněž ,ideologické“626) zázemí. Říká:

Široká perspektiva, o níž jsme hovořili v našich úvodních poznámkách, vyžaduje kooperaci mezi sociologií a filosofií. To není záležitost eklekticismu, nýbrž vyplývá to z problematiky těchto dvou disciplín samých (...). Sociologie má tendenci (...) stát se úzkým empirismem, který zapomíná na své vlastní teoretické základy (...). Sociologie, která reflektuje sebe sama a svůj předmět, musí být pokračujícím objasňováním každodenního života. Naplnění tohoto cíle předpokládá kritiku vědomí, která je vlastní náplní každodenního života (...). Analýza zvěcnění zde provedená může sloužit jako př́iklad možného smyslu setkání těchto dvou disciplín (sociologie a filosofie) v rámci sociologie vědění. (Berger a Pullberg 1965: 210-211)

Jedná se zřejmě o jeden z mála okamžiků, v nichž Berger rozpoznává, že jeho oddělování empirie a „ideologie“, resp. sociologie a filosofie, pro jeho sociální konstruktivismus nedává smysl.

\section{Závěr}

Ukazuje se, že to, co Berger ve většině svých textů staví jako „nehodnotící“ či „objektivní“ empirickou sociologii, je ve skutečnosti nástinem kritiky vědomí, která staví na silných ontologických předpokladech o ,autenticitě“, „svobodě“ a „správném“ typu vědomí. Jedná se

25 To neznamená, že Bergerova ontologie sociálního konstruktivismu není široce kompatibilní s žádnými jinými ontologiemi. Berger se domnívá, že některé věci mohou existovat současně jako konstrukt i nezávisle na lidech. Paradigmatickým př́íkladem pro tento názor je Bergerova víra v Boha (viz Berger 1969: 63-64).

26 Ztotožnění filosofie a ideologie je velkým problémem Bergerovy sociologie. Snaha oddělit sociologii od filosofie je u něho jasně korelativní ke snaze oddělit poznání od ideologie. To pak vede k tomu, že filosoficky zakotvené přístupy kritizuje jako „,agitprop“. 
o existencialisticky inspirovanou kritiku zaměřenou na šíření „pravdy“, jež spočívá v tom, že realita je údajně sociálně konstruována. Silný empirický základ této ,pravdy“ přitom Bergerovi umožňuje stavět tuto kritickou teorii jako „objektivní“ nebo „,nehodnotící“, což ale nic nemění na tom, že jeho sociologie je v posledku typem silného osvícenství, jehož evangeliem je v nejširším smyslu slova slavné Kantovo „sapere aude!“, „odvaž se vědět!“”, v užším smyslu pak blíže nerozpracovaná osnova svébytné verze kritiky odcizeného vědomí inspirovaná v existencialismu.

Do Bergerovy údajně „nehodnotící“ sociologie se hodnocení dostává skrze ontologický status „skutečnosti“ a epistemologický status ,pravdy“ konstruktivismu. Tato teorie je sociální ontologií, která je vưči některým alternativním ontologiím nekompatibilní. Ty pak pranýřuje jako „zvěcňující“ či „odcizené“ - to by si ovšem jako „nehodnotící“ samozřejmě neměla dovolit; koneckonců „odcizení“ neznamená jen kognitivní pomýlení, nýbrž znamená i stav vědomí, v němž se lidé „schovávaji““ za své role, aby se zbavili odpovědnosti za vlastní jednání. Jedná se tedy o stav, který Berger nakonec kritizuje z morálního hlediska.

Domnívám se, že tento status Bergerovy sociologie nejde jednoduše „sociologizovat“ pomocí vynechání jeho „fillosofických“ aspektů a ponechání těch „sociologických“. Zdá se totiž, že filosofické přesvědčení sociologickou empirii z velké části předchází; přichází spíše „před“ sociologií než „po“ ní. Vynechání filosofických aspektů by muselo být skutečně radikální, aby splnilo svůj účel. Musela by být opuštěna filosofická rovina sociologie vědění samotné - Berger by se musel zrreknout ontologického významu své teorie. Nemohl by říci, že realita skutečně je sociálně konstruována; musel by toto je dát do uvozovek.

Tím, že bychom se Bergerovu sociologii pokusili pouze „očistit“ od explicitního existencialismu a marxovských pojmů, bychom nedosáhli ničeho více než zamlžení jejího kritického a filosofického charakteru - což se koneckonců Bergerovi často stává. Dokud Berger zastává hledisko „objektivity“, zdá se mu, že jeho sociologie má subverzivní charakter záhadně „sama v sobě“ - ve smyslu akontextuálního „pravda vás osvobodí“. Takový dojem ale není než přehlížením kontextu - filosofických předpokladů sociologické empirie. Filosofický a kritický charakter ale přežívá i bez toho, že by byl nutně explicitně formulován; propadá se ovšem do nereflektovanosti - např. četba The Social Construction of Reality, která svůj filosofický charakter popírá, může být matoucí, protože čtenář se logicky domnívá, že čte „nehodnotící'“ sociologii, zatímco se jedná o subverzi s letmo naznačeným záměrem kritiky vědomí.

Výše rozvedený rozpor mezi subverzí a objektivitou vedl Baehra $\mathrm{k}$ odmítnutí Bergerovy subverze a prŕklonu k objektivitě. Ti, kdo odhalují fikce, jsou podle něho satirici (Oscar Wilde), historicky se neosvědčili (Karl Marx), anebo mají sklony k antihumanismu (Friedrich Nietzsche). Sociologie naproti tomu „existuje, aby něco vysvětlila“ či aby „se snažila porozumět“ (Baehr 2013: 385). Tím, že se Berger snaží „demaskovat“, se tak údajně proviňuje na sociologickém podniku: „Jestliže sociologie skutečně spočívá na (...) demaskování, jak tvrdí Berger, měl by to být důvod stáhnout pozvání (do sociologie) a zrušit párty“ (Baehr 2013: 389).

Domnívám se, že takový závěr není přiměřený. Přijmeme-li četbu Bergerovy sociologie vědění jako četbu nerozpracovaného nástinu kritiky vědomí, neobjeví se před námi ani antihumanismus, ani marxismus, ani pouhá satira. Neobjeví se dokonce ani provinění na 
hodnověrné tradici sociologického podniku - sociologie vědění obsahovala kritický hrot od počátku. Není třeba Bergerovu sociologii zbavovat nánosu „demaskování“ - daleko spíše je třeba zbavovat ji traumatu objektivismu, který, jak podotýká Gill (1988: 256), je „epistemologicky naivní“. Jestliže bychom toho dosáhli, objeví se před námi obraz zajímavé a životné sociologie vědění, jejíž humanismus spočívá v následování etických přesvědčení, která spočívají v apelu na to, co je považováno za lidskou svobodu. Při tomto typu čtení by už nadále nemuselo být pravdou to, na co poukazuje Sica (2016: 38), že totiž ostř́ kritického směřování sociologie vědění bylo Bergerem „otupeno“.

\section{Literatura}

BAEHR, Peter. 2013. „The Undoing of Humanism: Peter L. Berger's Sociology of Unmasking.” Society 50(4): 379-390.

BERGER, Peter L. 1969. The Social Construction of Religion. Harmondsworth: Penguin Books.

BERGER, Peter L. 1971. A Rumour of Angels. Modern Society and the Rediscovery of the Supernatural. Harmondsworth: Pelican Books.

BERGER, Peter L. 2003. „Co se to stalo sociologii?“ Pp. 177-182 in Peter L. BERGER. Pozvání do sociologie. Humanistická perspektiva. Brno: Barrister \& Principal.

BERGER, Peter L. 2003. Pozvání do sociologie. Humanistická perspektiva. Brno: Barrister \& Principal.

BERGER, Peter L. 2012. Dobrodružství náhodného sociologa. Jak vysvětlit svět a přitom nenudit. Brno: Centrum pro studium demokracie a kultury.

BERGER, Peter L. a Hansfried KELLNER. 1982. Sociology Reinterpreted. An Essay on Method and Vocation. Harmondsworth: Penguin Books.

BERGER, Peter L. a Thomas LUCKMANN. 1999. Sociální konstrukce reality. Brno: Centrum pro studium demokracie a kultury.

BERGER, Peter L. a Stanley PULLBERG. 1965. „Reification and the Sociological Critique of Consciousness." History and Theory 4(2): 196-211.

CHANCE, Bradley J. 2004. „A Pedagogy of Dealienation: A Case Study in the Application of Peter Berger's The Sacred Canopy.“ Teaching Theology and Religion 7(2): 101-107.

DRÁPALOVÁ, Marie. 2004. „Neodmítnuté pozvání.“ Biograf 11(1): 97-98.

FULLER, Robert C. 1987. „Religion and Empiricism in the Works of Peter Berger.“ Zygon 22(4): 497-510.

GILL, Jerry H. 1988. „Objectivity and Social Reality: Peter Berger‘s Dilemma.“ Philosophy Today 32(4): 256-269.

HUBÍK, Stanislav. 1999. Sociologie vědění. Praha: Sociologické nakladatelství.

MARADA, Radim. 1999. Bergeriov a Luckmanni̊v existenciální humanismus. Pp. 202-214 in Peter L. BERGER a T. LUCKMANN. Sociální konstrukce reality. Brno: Centrum pro studium demokracie a kultury.

MARADA, Radim. 2004. „Kritický intelekt a buržoazní věda: Pojednání o Bergerově Pozvání do sociologie.“ Biograf 11(1): 83-96.

SICA, Alan. 2016. „Social Construction as Fantasy: Reconsidering Peter Berger and Thomas Luckmann's The Social Construction of Reality after 50 Years." Cultural Sociology 10(1): 37-52.

VERA, Hector. 2016. „Rebuilding a Classic: The Social Construction of Reality at 50.” Cultural Sociology 10(1): 3-20.

WOODHEAD, Linda (ed). 2001. Peter Berger and the Study of Religion. London: Routledge. 
ZERUBAVEL, Eviatar. 2016. "The Five Pillars of Essentialism: Reification and the Social Construction of Objective Reality.” Cultural Sociology 10(1): 69-76.

\section{Autor}

Karel Hlaváček je doktorandem na Institutu sociologických studií Fakulty sociálních věd Univerzity Karlovy. Ve své odborné práci se zabývá zejména kritickou teorií a náboženstvím. Kontakt:k.hlavacek@seznam.cz 